Reidbord, H.W. \& HaWk, W.A. (1965) Idiopathic retroperitoneal fibrosis and necrotizing vasculitis. Report of a case with autopsy findings and etiologic considerations. Cleveland Clinic Quarterly, 32, 19.

RusT, J.A. \& MAAS, H.E. (1967) Pelvic retroperitoneal fibrosis with response to prednisolone. American Journal of Obstetrics and Gynecology, 98, 654.

Saldino, R.M. \& Palubinskas, A.J. (1972) Medial placement of the ureter: a normal variant which may simulate retroperitoneal fibrosis. Journal of Urology, 107, 582.

Saxton, H.M., Kilpatrick, F.R., Kinder, C.H., Lessof,
M.H., Mchardy-Young, S. \& Warole, D.F.H. (1969) Retroperitoneal fibrosis. A radiological and follow-up study of fourteen cases. Quarterly Journal of Medicine, 38, 159.

ShaheEn, D.J. \& Johnston, A. (1959) Bilateral ureteral obstruction due to envelopment and compression by an inflammatory retroperitoneal process: report of two cases. Journal of Urology, 82, 51.

WRIGHT, F.W. \& SANDERS, R.C. (1971) Is retroperitoneal fibrosis a self-limiting disease? British Journal of Radiology, 44, 511 .

\title{
Phaeochromocytoma with unilateral renal artery stenosis
}

\author{
C. Thomas \\ M.D. \\ R. K. KOLHATKAR
F.R.C.S.
}

N. L. SHARMA

M.D., F.R.C.P.(E)

S. G. DEODHARE

M.D., F.C.P.S.

Wanless Hospital, Miraj Medical Centre, Miraj, India

\begin{abstract}
Summary
A patient with renal artery stenosis due to compression by a phaeochromocytoma is described. He underwent nephrectomy and tumour removal successfully.

\section{Introduction}

The two common causes for renovascular hypertension are atherosclerosis and fibromuscular hyperplasia (Foster et al., 1975). Rarely, tumours adjacent to the hilum of the kidney may compress the renal artery and produce hypertension. Weidmann et al. (1969) reviewed seventeen such cases, and found phaeochromocytoma to be the most common tumour, occurring in eleven cases. Since then three further cases of phaeochromocytoma and renal artery stenosis have been reported (McBride and Fitz, 1971; Kaufman, Marks and Smith, 1974; Schwartz et al., 1974). In this paper, one case of phaeochromocytoma with unilateral renal artery stenosis is reported.

\section{Case report}

A 31-year-old man was admitted with chest pain and giddiness. Hypertension had been first detected 6 years previously at another hospital and the patient was taking anti-hypertensive drugs irregularly. On examination, his supine blood pressure was 250/180

Correspondence: Dr C. Thomas, Wanless Hospital, Miraj Medical Centre, Miraj (Maharashtra), India.
\end{abstract}

mmHg. Cardiovascular, respiratory and central nervous systems were normal. Optic fundi revealed narrowing of the arterioles and $a-v$ nipping. No abdominal bruit was heard.

Investigations gave the following results: $\mathrm{Hb} \mathbf{1 7 . 9}$ $\mathrm{g} / 100 \mathrm{ml}$; WCC $6000 / \mathrm{mm}^{3}$; blood urea $30 \mathrm{mg} / 100$ $\mathrm{ml}$; blood sugar $85 \mathrm{mg} / 100 \mathrm{ml}$; serum creatinine 1.0 $\mathrm{mg} / 100 \mathrm{ml}$, serum sodium $127 \mathrm{mEq} / \mathrm{l}$; serum potassium $3.7 \mathrm{mEq} / \mathrm{l}$. An intravenous phentolamine hydrochloride test caused a drop in systolic pressure of $40 \mathrm{mmHg}$, and a drop in diastolic pressure of $\mathbf{3 0}$ mmHg. Presacral air insufflation followed by a rapid sequence intravenous pyelogram revealed an irregular, poorly functioning, contracted right kidney. The left kidney appeared normal and no adrenal tumour was seen. Translumbar aortography showed a normal left renal artery, but the right renal artery was not visible and appeared occluded at its origin (Fig. 1). At operation, the right kidney was contracted and a tumour was found adherent to the hilum (Fig. 2). Dissection proved difficult and a nephrectomy was performed. The blood pressure fell immediately and the patient required vasopressors for several hours. The kidney measured $6 \times 3.5 \mathrm{~cm}$ and weighed $32 \mathrm{~g}$, while the tumour measured $4.5 \times$ $3 \mathrm{~cm}$ and weighed $26 \mathrm{~g}$. Microscopic examination of the tumour revealed cells typical of phaeochromocytoma. Microscopic examination of the kidney showed hyalinization of the glomeruli, and 


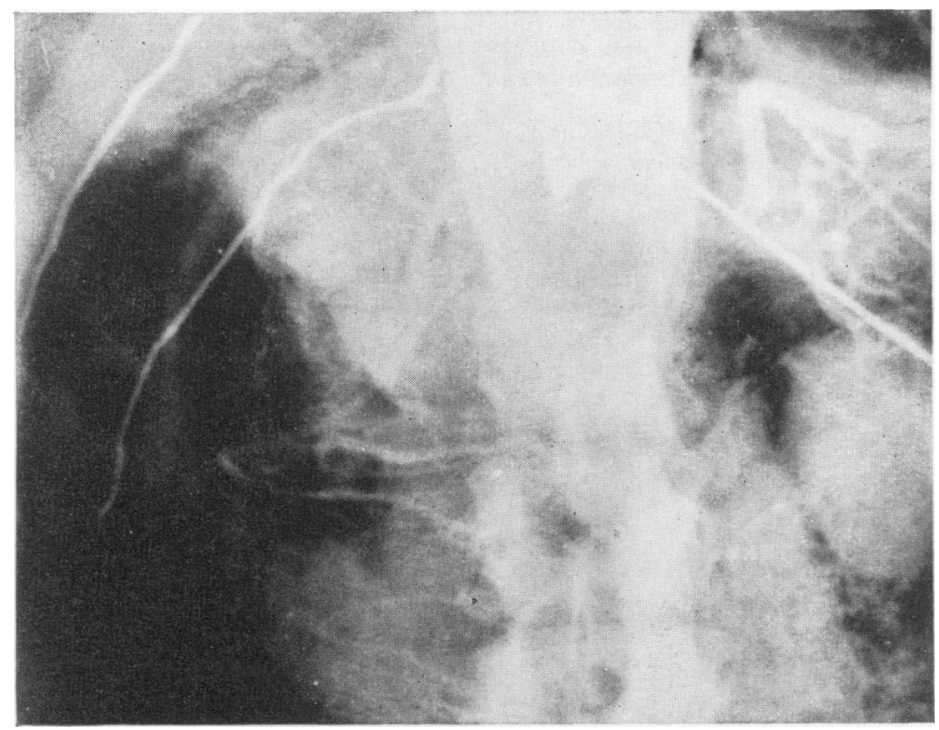

Fig. 1. Aortogram. Right renal artery not visible.

periglomerular fibrosis. The blood vessels showed intimal hyperplasia, and the interstitium was infiltrated with lymphocytes. Post-operatively, the patient remained asymptomatic for 4 months, but required small doses of anti-hypertensive drugs.

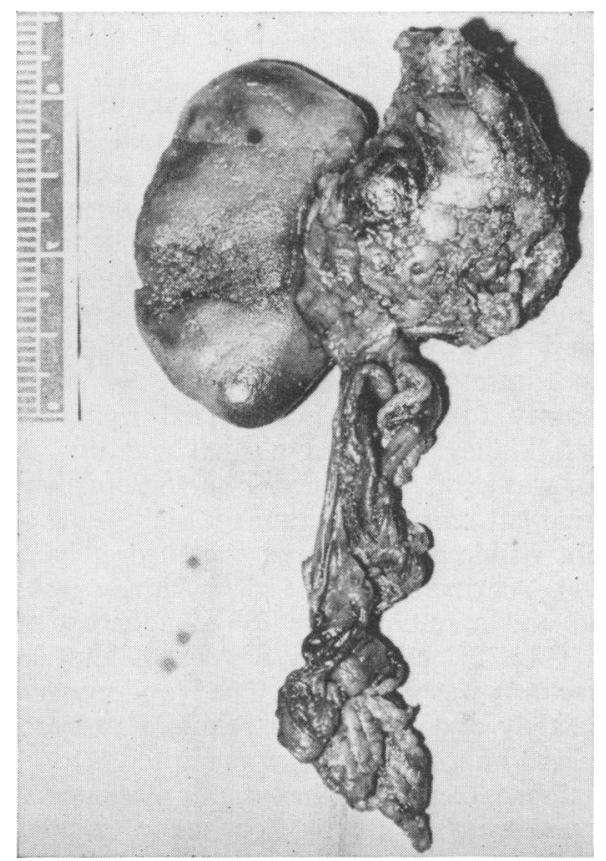

FIG. 2. Specimen of right kidney with phaeochromocytoma.
Discussion

Renal artery stenosis associated with phaee 3 chromocytoma was first described in 1958 (Harrison Gardner and Dammin, 1958). In some of the cases $\overrightarrow{0}$ reported subsequently, the renal artery stenost resulted from compression of the vessel by the tumour (Rosenheim et al., 1963; Kerzner et al., 1968), while in others, the renal artery stenosis was unrelated (Garrett et al., 1965; McBride and Fitz, 1971). In the case being reported, the tumour had $\frac{\circ}{\varnothing}$ caused extrinsic compression of the renal artery.

Although the phentolamine hydrochloride test $\overrightarrow{\overrightarrow{0}}$ showed a significant fall in blood pressure, the 3 possibility of a phaeochromocytoma causing renal artery stenosis was not considered before surgery. The intravenous pyelogram, presacral air insufflation $\bar{\partial}$ and aortogram suggested only a renal artery stenosis. Retrospective review of the aortogram did not reveal any areas of increased vascularity (Rosenheim et al., 1963).

Garrett et al. (1965) described a case treated by

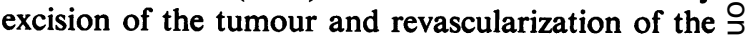
kidney by endarterectomy and patch grafting. In $D$ the present case, the tumour was closely adherent to the hilum of the kidney and a nephrectomy was $N$ unavoidable.

\section{References}

Foster, J.H., Maxwell, M.H., Franklin, S.S., Bleifer, $\omega$ K.H., TripPel, O.H., Julian, O.C., DeCAMP, P.T. \& VARADY, P.T. (1975) Renovascular occlusive disease. 6 Journal of the American Medical Association, 231, 1043.

GARReTt, H.E., SCotT, R., Howell, J.F. \& De BAKEy, M.E. (1965) Phaeochromocytoma and renal artery stenosis. Archives of Surgery, 90, 97.

HARRISON, J.H., GARDNER, F.H. \& DAMmin, G.J. (1958) A $\frac{\vec{D}}{\mathbb{D}}$ 
note on pheochromocytoma and renal hypertension. Journal of Urology, 79, 173.

Kaufman, J.J., MaRks, L.S. \& Smith, R.B. (1974) Stenosis of the renal artery and coexistent lesions. Surgery, Gynecology and Obstetrics, 139, 59.

Kerzner, M.S., Reeves, J.A., DeNyse, D. \& Claunch, B.C. (1968) Pheochromocytoma with renal artery compression in an identical twin. Archives of Internal Medicine, 121, 91.

MCBRIDE, J.W. \& FITZ, A. (1971) Renal artery stenosis, pheochromocytoma and erythrocytosis. American Journal of Medicine, 51, 403.
Rosenheim, M.L., Ross, E.J., Wrong, O.M., Hodson, C.J., DAviEs, D.R. \& SMITH, J.F. (1963) Unilateral renal ischemia due to compression of a renal artery by a pheochromocytoma. American Journal of Medicine, 34, 735.

Schwartz, S.I., LilleheI, R.C., Shires, G.T., SPEncer, F.C. \& StORer, E.H. (1974) Principles of Surgery, 2nd Edn, p. 1414. McGraw Hill, New York.

Weidmann, P., Siegenthaler, W., Ziegler, W.H., Sulser, H., Endres, P. \& Werning, C. (1969) Hypertension associated with tumors adjacent to renal arteries. American Journal of Medicine, 47, 528.

\section{Correlation between anti-DNA antibody titre and psychiatric manifestations in systemic lupus erythematosus}

\author{
Y. LEVO*
M.D. \\ A. I. PICK \\ M.D.

\begin{abstract}
Summary
A patient with systemic lupus erythematosus with predominant psychiatric involvement was followed during two psychotic exacerbations of her disease. A high correlation was found between disease activity and the titre of anti-DNA antibodies. Disease activity was preceded and accompanied by a high titre, while remission was associated with a low titre. The significance of this correlation for the pathogenesis, diagnosis and management of the psychiatric symptoms of systemic lupus erythematosus are discussed.
\end{abstract}

J. KALACI
M.D.

M. GolomB

M.D.

Department of Medicine B, Hypertensive-Renal Unit, and Section of Clinical Immunology, The Rogoff Institute for Medical Research, Geha Hospital, Beilinson Medical Center, The Sackler School of Medicine, Tel-Aviv University, Tel-Aviv, Israel

\section{Introduction}

Immune complexes, mainly of native DNA and its antibody, play a major role in the pathogenesis of systemic lupus erythematosus (SLE) (Koffler $e t$

\footnotetext{
* Present address: c/o Professor E. Franklin, Department of Medicine, New York University Medical Center, 550 First Avenue, New York, New York 10016, U.S.A.
}

al., 1971). A good correlation between high antiDNA antibody titres and low complement levels was observed during periods of active renal or cutaneous involvement in SLE patients (Oyama, 1971; Levo et al., 1973). The pathogenesis of central nervous system (CNS) involvement in SLE is possibly based on the same mechanisms (Bennett et al., 1972; Baker et al., 1974; Petz et al., 1971; Hadler et al., 1973; Keeffe, Baradana and Harbeck, 1974; Harbeck et al., 1973; Levin et al., 1972; Atkins et al., 1972; Bennahum and Messner, 1975). However, the correlation between cerebral manifestations in SLE patients and similar immunological parameters during various stages of their disease has not yet been established.

This report describes a patient with SLE with predominant psychiatric manifestations in whom a correlation was observed between serum anti-DNA antibody titres, complement levels and disease activity. 